\title{
DETECTION OF HISTAMINE AND TYRAMINE IN SOME
}

\section{CHEESE}

Thannae M. Amine*, Azza Mohamed Abouel Waffa*, Mona Omar Abou El-Nile*

\begin{abstract}
The biogenic amines content of various food has been widely studied because of their potential toxicity. This study aims at presenting data about histamine and tyramine content in some locally and imported soft, hard, and semihard cheese available in Alexandria markets throwing lights on its public health hazard. A total of 140 random cheese samples included a large variety of types of soft cheese (kareish, old cheese (Mish), Demietta), Semihard cheese, (Roquefort and Gouda), and hard cheese (Ras and Cheddar) as twenty samples of each were analysed for histamine and tyramine using high performance liquid chromatography (HPLC). Results showed that histamine and tyramine were detected in (35-55\%) and $(70-100 \%)$ of samples, respectively. All examined samples contained histamine level lower than the critical oral dose toxic to human (100 mg/100 g). Tyramine exceeded the dangerous dose for patients receiving MAOI, $(6 \mathrm{mg})$ by the percentage of $(30,100,60$, $100,50,80$, and $60 \%$ ), respectively. Histamin concentration increased in the order of cheddar > Mish $>$ Gouda $>$ Demietta $>$ Ras $>$ Roquefort $>$ Kareish cheese. Also, tyramine increased in these manner Roquefort $>$ Cheddar $>$ Mish $>$ Demietta $>$ Gouda $>$ Kariesh. The highest level of histamine and tyramine $(20.46 \pm 7.73$ and $32.76 \pm 10.32 \mathrm{mg} / 100 \mathrm{~g})$ recorded in cheddar and Roquefort cheese, respectively but the lowest level showed in kareish cheese $(4.02 \pm 1.74$ and $7.12 \pm 3.75 \mathrm{mg} / 100 \mathrm{~g})$ of histamine and tyramine, respectively.
\end{abstract}

\section{INTRODUCTION}

Biogenic amines are defined as low molecular weight organic basic, aliphatic mono or polyamines, aromatic or heterocytic amines are naturally formed as a consequence of metabolic process of human, animal, plant, and microorganism (Davidek and Davidek, (1995) $)^{(1)}$.
Decarboxylation of the protein amino acids by bacterial enzymes gives rise to formation of biogenic amines (Vale and Gloria, 1997)(2). They are commonly present in high concentration in a wide range of fermented and non-fermented products including fish, meat, and dairy

\footnotetext{
*Food Hygiene and Animal Health, Research Institute, Doki, Giza
} 
products (Maiijala et al., 1995; Moret and Conte 1996)(3,4).

Biogenic amines in food are formed during storage, spoilage, and ripening process through degradation of protein by proteolysis together with bacterial action resulting in formation of amino acids as precursors of biogenic amines produced through the decarboxylation process (Rice et al., 1976; Summer et al., 1990; and Silla Santos 1996)(5-7).

Biogenic amines are undesirable compound in food because of their potential to affect the well being of consumers or even to cause serious health problems for susceptible persons.

Cheese are among those high proteincontaining food stuffs in which microbial activity results in the formation of such products of protein decomposition as biogenic amines. Cheese represent an ideal environment for amine production by bacterial decarboxylation of appropriate amino acids. Amounts of biogenic up to $1 \mathrm{~g} / \mathrm{kg}$ have been found in cheese products (Silla. Santos, 1996; Chang et al., 1985; Innocente, et al., 2007:(7-9).

Tyramine histamine, putrescine, cadaverine, phenylanine, spermine, and spermidine are generally considered to be the most important biogenic amines occurring in cheese (Joosten, 1988; Stratton et al., 2000)(10-11). The most notorious food borne intoxation caused by biogenic amines are related to histamine.

Histamine at levels usually exceeding $1000 \mathrm{mg} / \mathrm{kg}$ has been implicated with certain food intoxications such as scombrotoxicosis (Taylor and Speckhard 1984).(12) or the cheese syndrome (Taylor et al., 1982, Summer, et al., 1985, and Stratton, et al., 1991).(13-15) Also amines in dairy products at high levels could be of great public health significance because of their possiblity in involvement in intestinal ulcers and allergic responses (USFDA, 2001; and Periago, 2003).(16,17) Several out breaks of histamine poisining have 
occurred following consumption of cheese (particularly Swiss and Cheddar) containing high levels of histamine, Taylor et al., (1982). ${ }^{(13)}$ Tyramine may provoke hypertensive crises and even death from cerebral hemorrhage in patients treated with monoamine oxidase inhibitor drugs. Migraine headache has been triggered by consumption of cheese with high level of tyramine. Also, those amines may form nitrosamines compounds known to be carcinogenic, mutagenic, and teratogenic. (Stratton et al., 1991; Tailor, et al., 1994; Landete, et al., 2005).(15,18,19) Regulatory levels in the range of $50-200 \mathrm{mg}$ of histamine/kg of fish tissue have been set by European Union, the U.S., FDA, Egyptian standars and other countries (European Union, 1991; Egyptian Standars, 1996; Flitcher et al., 1998).(20-22). Despite the fact that cheese may contain exceedingly high level of histamine and other biogenic amines (> $2000 \mathrm{mg} / \mathrm{kg}$ ), tolerance has not been set so far (Osman et al., 1999).(23) The level of biogenic amines in cheese is necessary to assess the health hazard arising from consumption of these products furthermore, it could be useful as a chemical index in quality assurance of material and manufacturing conditions since these tests are rapid compared to traditional microbial analysis, less subjects individual interpretion than sensory analysis.

So this study was done to obtain quantitative information for histamine and tyramine in some locally, imported soft, hard, and semihard cheese available in Alexandria markets concerning its public health.

\section{MATERIAL AND METHODS}

\section{Sample materials}

A total of 140 random cheese samples were collected separately from different retail food markets in Alexandria, including a large variety of soft cheeses (Kareish, Old cheese, and Demietta), semihard 
cheeses (Roquefort and Gouda), and hard cheeses (Ras and Cheddar) as twenty samples of each. A 100-200 g portion of each sample was get up in a blender at high speed for $2 \mathrm{~min}$ and stored at $-18^{\circ} \mathrm{C}$ until analysis.

Analysis of biogenic amines (Histamine and Tyramine): was used by high performance liquid chromatography (HPLC) according to the methods described by Mitz and Karamas (1978)(24) and Vale \& Gloria, (1997).(2)

$50 \mathrm{~g}$ of ground sample was extracted with $5 \%$ trichloroacetic acid (TCA) $3 \times 75$ $\mathrm{ml}$ using a warning blender. Each blended mixture was centrifuged and the clear extracts were combined. The value was adjusted to $250 \mathrm{ml}$ with TCA (5\%) solution. The equivalent of $2 \mathrm{~g}$ of sample as the TCA extract $(10 \mathrm{ml}$ was made alkaline by adding $1 \mathrm{ml} 50 \%$ sodium hydroxide and then extracted with $\mathrm{n}$-butanol/chloroform mixture $(1: 1 \mathrm{v} / \mathrm{v}) 3 \times 5 \mathrm{ml}$. The combined organic phase after addition of an equal of $n$. heptane $(15 \mathrm{ml})$ was extracted with several potions of 0.02 ( $1 \mathrm{ml}$ each) and the aqueous extract was dried using current of air.

\section{Derivatives formation and determination}

The dansyle derivatives of biogenic amines were formed by adding saturated sodium bicarbonate solution $(0.5 \mathrm{ml})$ to the residue (dry film) stoppered and carefully mixed using vortex mixer, then carefully adding $1 \mathrm{ml}$ dansyle chloride solution (500 $\mathrm{mg}$ in $100 \mathrm{ml}$ acetone) and mixed thoroughly. After standing for more than 10 hours at room temperature, the densyl amines were extracted by adding $15 \mathrm{ml}$ HPLC grade water and then the mixture was extracted with several portion $(5 \mathrm{ml}$ each) of diethyl ether (HPLC grade). The combined ether extracts were then evaporated to dryness by the aid of current of air and water bath at $35^{\circ} \mathrm{C}$. The residue was dissolved in $1 \mathrm{ml}$ acetonitrile.

\section{Preparation of standard solution:}

\section{Histamine}


Dissolving $41.40 \mathrm{mg}$ of histamine Program : gradient program $60 \%$ solvent B dihydrochloride (Sigma Chemical Co, N. in solvent A to $100 \%$ solvent B using linear 7505) in $50 \mathrm{ml}$ water HPLC grade (stock program over $30 \mathrm{~min}$ period and $1 \mathrm{ml}$ constant solution $0.5 \mathrm{mg} / \mathrm{ml}$ ) flow rate.

\section{Tyramine}

Detector: UV-Vis at $254 \mathrm{~nm}$.

Dissolving $31.39 \mathrm{mg}$ of tyramine (4hydroxphenyl ethylamine) hydrochloride ( $N$, T-2879) in $50 \mathrm{ml}$ water HPLC grade (stock solution $0.5 \mathrm{mg} / \mathrm{ml}) 200 \mathrm{ml}$ of each stock standard solution was transferred to glass tube (using micropipette) then evaporated using current of air. The residue was subjected to densylation. Then the residue was dissolved in $5 \mathrm{ml}$ acetonitrile $(1 \mathrm{ml}=20$ $\mu \mathrm{g}$ or/oug $=0.2 \mu \mathrm{g}$ each amine as derivative) .

\section{Detection}

HPLC was used for the quantitative estimation of biogenic amines. The conditions used were as follow:

Mobile solvent: solvent $A$ : acetonitrile $0.02 \mathrm{~N}$ acetic acid (1: $9 \mathrm{v} / \mathrm{v})$.

Solvent B : $0.02 \mathrm{~N}$ acetic acid: acetonitrile: methanol (2: $9: 9 \mathrm{v} / \mathrm{v} / \mathrm{v})$.

Column : reversed phase: C18 shin pack. CLC. ODS, $0.15 \mathrm{~m} \times 6.0$.

Injection : $10 \mathrm{ml}$ of standard solution (as derivative) or sample was injected into HPLC apparatus.

\section{RESULTS AND DISCUSSION}

Tables (1-3) and Fig. (1) illustrated the percentage of detected positive samples and concentrations of histamine and tyramine $(\mathrm{mg} / 100 \mathrm{~g})$ in some cheese (Kareish, Old cheese (Mish), Demietta, Requfort, Gouda, Cheddar, and Ras) collected from different retail food markets in Alexandria. It is clear from these data, that, there were wide variations in the content of both histamine and tyramine versus the type of cheese and also, between samples of the same type may be attributed to the variation 
of ripening time, microbial action, precursor amino acids, $\mathrm{pH}$, temperature and raw material quality and decarboxylase enzyme activity (Genigeorges, 1976; Daher \& Simard, 1985; Barath, et al., 1991; and Elleboudy \& El-Mossilami, 2006).(25-28)

Data in table (1) decleared that $70-100 \%$ of examined samples contained detectable level of tyramine, meanwhile histamine could be detected in $35-55 \%$ of samples.

Table (2) and Fig. (1) revealed that the histamine concentrations were significantly higher in Cheddar and old cheese (Mish) with the mean value $20.47 \pm 7.73$, $19.05 \pm 6.26 \mathrm{mg} / 100 \mathrm{~g}$, respectively, followed by Gouda cheese with $18.14 \pm 4.04 \mathrm{mg} / 100$ g. The lowest level of histamine showed in Kareish and Roquefort cheese were $4.02 \pm 1.74$ and $4.66 \pm 2.52 \mathrm{mg} / 100 \mathrm{~g}$, respectively while Ras and Demietta cheese showed the nearly similar level $(13.33 \pm 5.42$ and $14.33 \pm 8.04 \mathrm{mg} / 100 \mathrm{~g}$ ), respectively.

With respect to tyramine concentration, table (3) and Fig. (1) showed the highest significant mean concentration value in Roquefort cheese $(32.76 \pm 10.32 \mathrm{mg} / 100 \mathrm{~g})$. However, in Mish and cheddar cheese, the levels of tyramine were $19.29 \pm 4.06$ and $21.89 \pm 10.20 \mathrm{mg} / 100 \mathrm{~g}$, respectively. The relatively lower level of tyramine were recorded in Kariesh, Ras, Gouda, and Demietta cheese with mean values of $(7.19 \pm 3.75, \quad 8.25 \pm 2.33, \quad 10.29 \pm 4.95$ and $11.22 \pm 2.72 \mathrm{mg} / 100 \mathrm{~g}$ ), respectively. It could be concluded that total level and positive detected percentage of tyramien in examined samples were higher than that of histamine these may be attributed to the high concentration level of the amino acid tyrosin (precursor to tyramine) as discussed by De Borba and Rohrer 2008).(29)

A relatively higher concentration of tyramine is present in fresh and spoiled cheedar cheese upon spoiling tyramine increased more than four times its original concentration from 15.4 to $65.32 \mathrm{mg} / 100 \mathrm{~g}$ while histamine only increased slightly from 12.5 to $15.2 \mathrm{mg} / 100 \mathrm{~g}$ may be due to the 
percent of high levels of E.coli and Enterocuccus faecalis capable of producing tyramine (Silla Santos, 1996(7); Marino et al., 2000(30), El-Sheshnagui, 2006(31), De Borba and Rohrer, 2008), (29). and Vale and Gloria (1998). (32) determined histamine in 65\% and tyramine in $38 \%$ of Brazilian cheese samples with concentration of 19.65, 21 . and $25 \mathrm{mg} / 100 \mathrm{~g}$, respectively.

Voigt et al., (1974)(33) reported that tyramine concentration generally increased with degree of flavor development whereas formation of histamine occurred less frequently than tyramine. Tyramine was the most prevalent with the highest maximum concentration in Kareish and Demietta cheese (El-Labody et al., 1995). ${ }^{(34) .}$

The Lower level of tyramine in soft cheese (Kariesh and Demietta) in comparison to hard cheese may be due to short ripening period required for production and rapid increase in $\mathrm{pH}$ of cheese which would decrease tyrosine decarboxyelase activity, (Vidaud, et al., 1987, Leuschner, et al., 1998 and El-Mossalami, 2003.(35-37)

In general, the achieved data were nearly in accordance with El-Mossalami, (2003).(37) which recorded the relatively similar range and mean values of histamine and tyramine in Kareish and Ras cheese in contrast with more levels that were detected in Demietta cheese. Also histamine concentration level in Mish (old cheese), and Gouda cheese is nearly in agreement with those reported by Chambers and Staruszkiewics (1981).(38) Stratton et al., (1991) $^{(15)}$ and Neamat-Allah (1997). ${ }^{(39)}$

From another point, our results were in contrast with (Prete et al., 1979),(40) Tawfik et al., (1992).(41) Darwish, et al., (1994)(42) ElLeboudy et al., (1995)(34), and De-borba \& Rohrer (2008).(29) They detected lower histamine content in Gouda, Ras, Kariesh and Cheddar cheese, respectively. However, Voigt et al., 1974(33), El-Zyat and Bagoury, 1988(43), and Stratton et al., 
1991)(15) revealed more higher content of histamine in Demietta, Requefourd, and chedder cheese in comparison with our results.

On the other hand, tyramine concentration showed nearly similar values with those reported by Voight et al., (1974),(33) Reuvers et al., (1986),(44) Brink et al., (1990)(45), ElLeboudy (1995)(34), and Neamat-Allah (1997)(39). Other researchs conducted by ElZyat and El-Bagoury, 1988)(43), and Vidaud et al., (1987).(35) had indicated higher level of tyrammine in Demietta, Roquefort, Ras, and Chedder cheese than those recorded in this study in contrast with lower level of tyramine recorded by Stratton, et al., (1991)..(15)

Amines particularly histamine and tyramine presence in food at high levels could be great public health hazards. Although there is no regulatory limits for histamine and tyramine in cheese, our study showed that all investigated samples contained histamine below $100 \mathrm{mg} / 100 \mathrm{~g}$. The critical dose of oral histamine has been suggested to induce toxic response in humans (Treptow and Askar, (1996). $\left.{ }^{(41}\right)$ With respect to the hazard level of tyramine which was reported to be dangerous dose for patients receiving MAOI, (6 mg), Blackwell \& Mabbit (1965) ${ }^{(47)}$. The percentage of $(30,100$, $60,100,50,80$, and 60\%) in Kariesh, Mish, Demietta, Roquefort, Gouda, Chedder, and Ras Cheese, respectively contained tyramine in a higher level than these detected limit $(6$ $\mathrm{mg}$ ). Biogenic amines are heat stable, histamine is more commonly the result of high temperature spoilage than of long term, Jargensen, et al., (2000). ${ }^{(48)}$

Generally, we concluded that biogenic amines in food can be controlled by strict use of good hygiene in both raw material and manufacturing environment with corresponding inhibition of spoilage microorganisms and finally proper storage temperature. In addition, it is of great importance to establish regulatory limits for all biogenic amines which may be found in cheese to safeguard public health. 
Table (1): Positive samples of biogenic amines in examined cheese $(n=20)$

\begin{tabular}{|c|c|c|c|c|c|c|c|c|}
\hline & \multirow[b]{2}{*}{$\begin{array}{l}\text { Type of } \\
\text { cheese }\end{array}$} & \multicolumn{3}{|c|}{ Soft } & \multicolumn{2}{|c|}{ Semihard } & \multicolumn{2}{|c|}{ Hard } \\
\hline & & Kareish & $\begin{array}{c}\text { Old } \\
\text { Cheese } \\
\text { (Mish }\end{array}$ & Demietta & Roquefort & Gouda & Cheddar & Ras \\
\hline \multirow{2}{*}{$\frac{\frac{\pi}{0}}{\frac{0}{I}} \cdot \frac{\bar{E}}{\varepsilon}$} & $\begin{array}{l}\text { No. of +ve } \\
\text { samples }\end{array}$ & 9 & 10 & 7 & 9 & 8 & 10 & 11 \\
\hline & $\%$ & 45 & 50 & 35 & 45 & 40 & 50 & 55 \\
\hline \multirow{2}{*}{$\stackrel{\frac{\pi}{2}}{\frac{\Xi}{E}}$} & $\begin{array}{l}\text { No. of +ve } \\
\text { samples }\end{array}$ & 14 & 17 & 16 & 20 & 20 & 18 & 15 \\
\hline & $\%$ & 70 & 85 & 80 & 100 & 100 & 90 & 75 \\
\hline
\end{tabular}

Table (2): Statistical analysis of Histamin content among positive examined cheese samples $(\mathrm{mg} / 100 \mathrm{~g})$

\begin{tabular}{|l|c|c|c|c|c|c|c|}
\hline \multirow{2}{*}{$\begin{array}{l}\text { Type of } \\
\text { cheese }\end{array}$} & \multicolumn{3}{|c|}{ Soft } & \multicolumn{2}{c|}{ Semihard } & \multicolumn{2}{c|}{ Hard } \\
\cline { 2 - 8 } & Kareish & $\begin{array}{c}\text { Old Cheese } \\
\text { (Mish }\end{array}$ & Demietta & Roquefort & Gouda & Cheddar & Ras \\
\hline Min & 0.22 & 7.80 & 0.21 & 0.89 & 7.75 & 6.73 & 0.73 \\
\hline Max & 9.65 & 48.00 & 53.50 & 16.80 & 36.03 & 58.00 & 38.73 \\
\hline Mean & 4.02 & 19.50 & 14.33 & 4.66 & 18.14 & 20.47 & 13.33 \\
\hline $\mathbf{\pm S . E}$ & $1.74^{\mathrm{a}}$ & $6.26^{\mathrm{ab}}$ & $8.04^{\mathrm{ab}}$ & $2.52^{\mathrm{ab}}$ & $4.04^{\mathrm{ab}}$ & $7.73^{\mathrm{b}}$ & $5.42^{\mathrm{ab}}$ \\
\hline
\end{tabular}

Different superscripts are significant at $(p<0.05)$

Table (3): Statistical analysis of Tyramine content among positive examined cheese samples $(\mathbf{m g} / \mathbf{1 0 0 g})$

\begin{tabular}{|c|c|c|c|c|c|c|c|}
\hline \multirow{2}{*}{$\begin{array}{c}\text { Type of } \\
\text { cheese }\end{array}$} & \multicolumn{3}{|c|}{ Soft } & \multicolumn{2}{c|}{ Semihard } & \multicolumn{2}{c|}{ Hard } \\
\cline { 2 - 8 } & Kareish & $\begin{array}{c}\text { Old Cheese } \\
\text { (Mish }\end{array}$ & Demietta & Roquefort & Gouda & Cheddar & Ras \\
\hline Min & 0.46 & 4.47 & 3.09 & 7.44 & 0.58 & 0.45 & 0.50 \\
\hline Max & 25.38 & 29.21 & 21.49 & 71.46 & 32.86 & 70.00 & 17.25 \\
\hline Mean & 7.19 & 19.29 & 11.22 & 32.76 & 10.29 & 21.89 & 8.25 \\
\hline $\mathbf{\pm S . E}$ & $3.75^{\mathrm{a}}$ & $4.06^{\mathrm{ab}}$ & $2.72^{\mathrm{a}}$ & $10.32^{\mathrm{b}}$ & $4.95^{\mathrm{a}}$ & $10.20^{\mathrm{ab}}$ & $2.33^{\mathrm{a}}$ \\
\hline
\end{tabular}

Different superscripts are significant at $(p<0.05)$ 


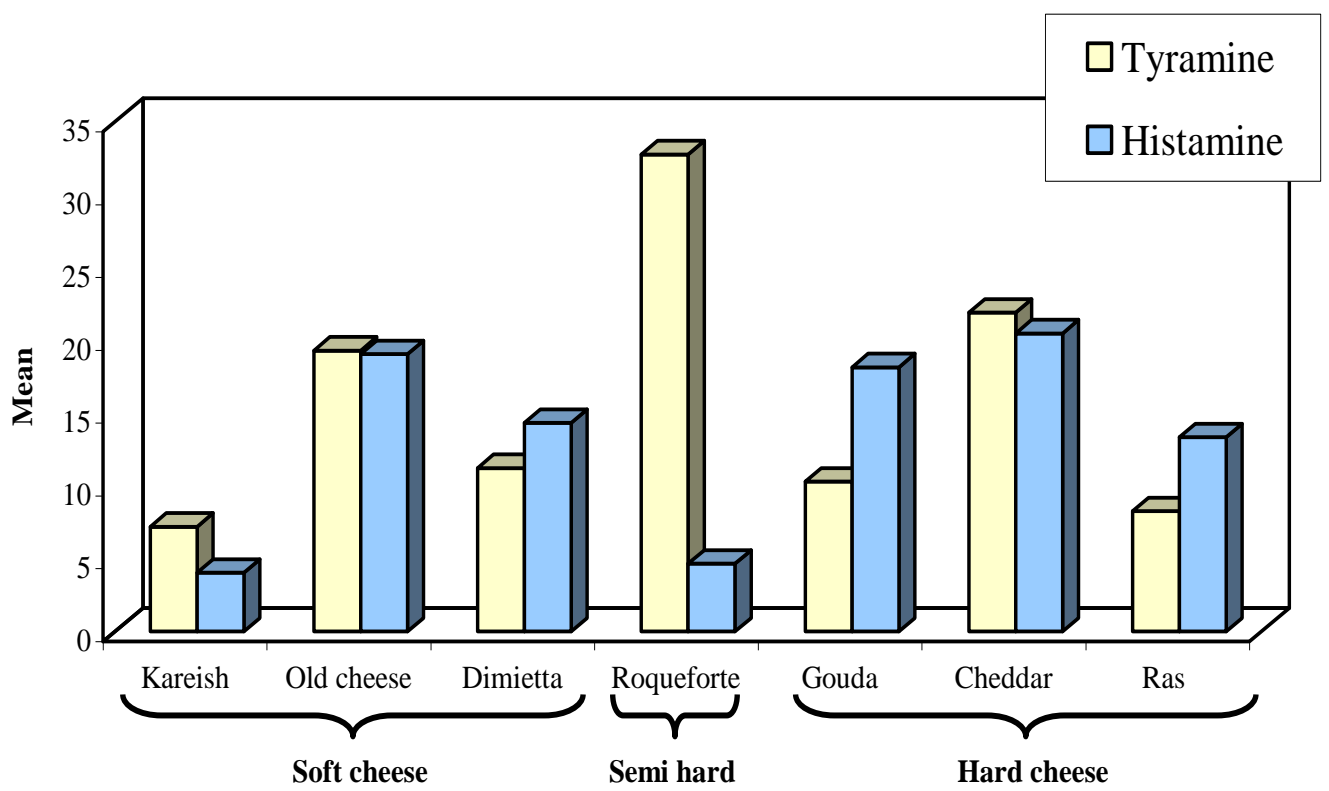

Figure (1): Statistical analysis of histamine and Tyramine concentrations ( $\mathrm{mg} / 100 \mathrm{gm})$ of different examined cheese samples.

\section{REFERENCE}

1. Davidek TM, Davidek J. Biogenic amines. In: Davidek J. Natural toxic compounds of foods. Bocaraton F.I: CRC Press; 1995. 108-123.

2. Vale SR, Gloria MB. Deteermination of biogemic amines in cheese. J AoAc INT. 1997;80 (5). 1006-12

3. Maijala R, Eerola S, Lievonen S, Hill P, Hirvi T. Formation of biogenic amines during ripening of dry sausages as affected by starter culture and thawing time of raw materials. J Food Sci. 1995; 60: 1187-90.

4. Mortet S, Conta L. High performance liquid chromatography evalution of biognic amines in foods An analysis of different methods sample preparation in relation characteristics. $\mathrm{J}$ Chromatography A. 1996;729-363-9.

5. Rice SL, Eitenmiller RR, Koehler PE. Biologically active amines in food $A$ review. J Milk Food Technol. 1976;39(5): $353-8$.

6. Summer SS, Roche F. Taylor SL. Factors controlling histamine production in Swiss cheese inoculated with Lactobacillus buchneri. J Dairy Sci. 1990;73(11): 3050-8

7. Silla-Santos MH. Biogenic amines: Their importance in foods. Int J Food

Microbiol. 1996;29: 213-31.

8. Chang SF, Ayres JW, Sandine WE. Analysis of cheese for histamine, 
tyramine, tryptamine, histidine, tyrosine and tryptophane. J Dairy Sci. 1985;68: 2840-6.

9. Innocente $\mathbf{N}$, Biasutti $\mathbf{M}$, Pdovese $\mathbf{M}$, Moret S. Determination of biogenic amines in cheese using HPLC technique and direct derivatization of acid extract. Food Chemistry. 2007;101 (3): 1285-9.

10. Joosten HMLJ. The biogenic amine contents of Dutch cheese and their toxicological significance. Nether. Milk Dairy J. 1988;42(1): 25-42.

11. Stratton JE, Hutkins RW, Taylor SL. Biogenic amines in cheese and other fermented foods. A view. J Foot Protection. 1991;54:460;70.

12. Taylor SI, Speckhard MW. Inhibition of bacterial histamine production by sorbate and other antimicrobial agents. J. Food Prot. 1984; 47: 508-11.

13. Taylor, S.I.; Keefe, T.J.; windham, E.S. Howell, J.F. Outbreak of histamine poisoning associated with consumption of Swiss cheese. J. Food Prot.,1982; 45(5): 455-457.

14. Sumner SS, Speckhard MW, Somers EB, Taylor SL. Isolation of histamineproducing Lactobacillus buchneri from Swiss cheese implicated in a food poisoning outbreak. Appl. Environ Microbiol., 1985;50(4): 1094-6.

15. Stratton JE, Hutkins RW, Taylor SL. biogenic amines in cheese and other fermented foods: A review. J. Food Prot. 1991:54(6): 460-70.

16. US Food and Drug Administration, Center for food safety and Applied Nutrition Scombrotoxin (histamine) formation. In: Fish and fishery products hazards and control guide (2001): $3^{\text {rd }}$ ed. Washington, DC: Department of Health and Human Services, Public Health Service, Center for Food Safety and Applied Nutrition. Office of Seafood; June
2001. 73-102.

17. Periago MJ, Rodrigo J, Ros G, Rodrigue J, Hernandez-Herrero $M$. Pathopathology of biogenic toxicity in Spanish fish products. Department of food Science and Nutrition, Faculty of Veterinary Science and food Science and technology. Murica, Spain: Murica University; 2003.

18. Tailor SA, Shulman KI, Walker SE, Moss J, Gardens D. hypertensive episode associated with phenelzine and tap beer. A reanalysis of the role of pressor amines in beer. J. Clin. Psychopharamacol. 1994;14: 5-14.

19. Landete JM, Ferrers P, Pardol L. Biogenic Amines in wines from Spanish regions, J. Agric Food Chem. 2005;53(4): 1119-24.

20. European Union Council-Directive. 91/493/EEC of July 1991 laying down the health conditions for the production and the placing on the market of fishery production and the placing 0 the market of fishery products. Off. J Eur Communities. 1991, L268.

21. Egyptian Organization for Standardization and Quality Control. Egyptian Standards Specification. 1996.

22. Fletcher GC, Summers G, Van Veghel PWC. Level of histamine and histamine producing bacteria in smoked fish from New Zealand markets. J food Prot. 1998; 61 106470.

23. Aggün $\mathrm{O}$, Elisabeth $\mathrm{S}$, Rainer $\mathrm{S}$, Ewald U, Manfred, G, Erwin M. comparison of ELISA and HPLC for the determination of histamine J. Agric food Chem. 1999;47, 1961-4.

24. Mietz JL, Karmas E. Polyamine an histamine content of Rockfish, salmon, lobster and shrimp as an indicator of 
decomposition. J Assoc Off Anal. Chem. 1978;61: 139-45.

25. Genigeorges CA. Quality control for fermented meat. J Amer Vert Med Assoc. 1976;169: 1220-8.

26. Daher NS, Simard RE. Putrefactive amine changes in relation to microbial counts of ground beef during storage. Food Prot. 1985;48: 54-8.

27. Barath A, Halasz A, Holzapfel W. Biogenic amine concentration in some food items. Elelmezesi - Ipar (Hungary). 1991;45: 286-91.

28. El-Leboudy AA, Hanaa H, ElMossalami A. Proteolytic microorganisms in curd dairy products with reference to histidine decarboylase Activity on Niven Modified Medium. the Second Scientific Congress, Fact Vet Med. Kafr- El Sheikh Vol 4. No 1. 2006.

29. De Borba B, Rohrer J. Bionex corporation 1228 titan way, Sunnyvale. Determination of biogenic Amines in spoiled cheese by lon Chromatography with intergrated pulsed Amperomet ric detection. 2008.

30. Marino M, Maifreni M, Morset S, Rondinini G. The capacity of enterobacteriaceae species to produce biogenic amines in cheese. Lett App Microbiol. 2000;(2): 169-73.

31. Sawsan ML, El-Sheshnagui. Level of Histamine in Relation to the Hygienic quality of some seafood from Alexandria Markets $8^{\text {th }}$ Sci Vet, Med. Zag. Conference. (31 Aug-3 Sep. 2006):123-134.

32. Vale S, Gloria MBA. Biogenicamine in Brazilian cheeses. Food Chemistry. 1999;63(3) 343-8.

33. Voigt MN, Eitenmiller RR, Koehler PE, Hamady MK. Tyramine, histamine and tryptamine content of cheese. J Milk Food Technol. 1974;37: 377-81.
34. El-Leboudy AA, Taha NM, El-Kholy A. Biogenic Amines content of Egyptian soft cheese and its public health significance. ISSN 110-2047. Alex J Vet Sci. 1995;11(1): 1-5.

35. Vidaud J, Chaviano E, Esther G, Garcia R. Tyramine content of some Cuban cheese, Die Nahrung1987;3(3) 221-4.

36. Leuschner RG, Kurihara R, Hammes WP. Effect of enhanced proteolysis on formation of biogenic amines by lactobacilli during Gouda cheese ripening. $J$ Food Microb. 1998;44(1\&2):15-20.

37. El-Mossalam HH. Proteolytic. microorganism in curd dairy products with special reference to biogenic amines content. Cited from Ph. D thesis. Fac Vet Med, Alex Univ, Egypt. 2003

38. Chambers TL, Staruszkiewicz WF. Fluorometric determination of histamine in cheese. J Assoc off Anal Chem. 1978;61(5); 1092-7.

39. Neamat-Allah AA. Biogenic amines in kareish and mish cheese in Egypt. Dairy Depart. Fac. Agric, Al-Azhar Univ. Nasr City, Cairo. Egyptian Dairy Sci. 1997;25: 337-48.

40. Prete UD, Amodio R, Montanaro D. Histamine content of some food products. Rivista della Societa Italiana di Scienza dell alimentaione. 1979;8(5): 281-6. Dairy Sci. Abst. 1980; 42(12): 960.

41. Tawfik NF, Shalaby AR, Effat BA. Biogenic amine contents of Ras cheese and incidence of their bacterial producers. Department of Food Technology and Dairying, National Res Cent, Dokki, Cairo, Egypt. Egyptian J Dairy Sci. 1992;20: 29-225.

42. Darwish SM, El-Difrawy R, Mashaly R, Aiad E. An assay for bitter peptides, amino acids, biogenic 
amines, glycerides and fatty acids, in the bitter Ras cheese on local market. Food Science Dept, Fac Agric (Saba Basha), Alex., Univ. and Dept. of agricultural Industries, Alexandria Univ. Egyptian J Dairy Sci. 1994;22: 110.

43. El-Zayat Al, El-Bagoury EH. Tryptamine, tyramine and histamine content of Domiati, Ras and Roquefort cheese. Zeitschrift-furdie-Gesamte-Hygiene-UndihreGrenzgebiete. 1986;32: 7, 410-1.

44. Reuvers ThBA, Martin-de Pozuelo M, Ramos M, Jimenez $\mathbf{R}$. A rapid ionpair HPLC procedure for the determination of tyramine in dairy products. J Food Sci. 1986;51(1): 84-6.
45. Brink BT, Damink C, Joosten HMLJ, Huis int Veld JHJ. Occurrence and formation of biologically active amines in foods. Int J Food Microbiol. 1990;11: 73-84

46. Treptow H, Askar A. Biogenicamine in Lebensmitteln. Fleish- und Fleischerzeugnisse, Fisch und Fiscerzeugnisse. In biogene Amine in der Ernahrung; Beutling, D., Berlin, Germany: Ed Springer; 1986.135-154.

47. Blackwell B, Mabbit LA. Tyramine in cheese related to hypertensive crises after MAO inhibition. Lacent 1. 1965;(5): 938-941.

48. Jargensen LV, Dalgaard $P$, Huss $\mathrm{HH}$. Biogenic amines in food. J Agric Food Chem. 2000;48:2448-5. 

